\title{
The Effects of Organisational Culture on IFRS Adoption: Evidence from Nigerian' Companies
}

\author{
Jude Edeigba (Corresponding author) \\ Department of Financial and Business Systems, Faculty of Agribusiness and Commerce \\ P.O. Box 85013, Lincoln University, Ellesmere Junction Rd, Lincoln 7647, New Zealand \\ E-mail: jude.edeigba@lincolnuni.ac.nz
}

\author{
Christopher Gan \\ Professor, Department of Business and Finance, Faculty of Commerce \\ Department of Accounting, Finance and Economics \\ P.O. Box 85084, Lincoln University, Christchurch, New Zealand
}

Felix Amenkhienan

Professor, Department of Accounting, Finance and Business Law

Box 6951, Radford University, Virginia 24142, USA

Received: February 24, 2018

Accepted: March 6, 2018 Published: March 14, 2018

doi:10.5296/ijafr.v8i1.12713

URL: https://doi.org/10.5296/ijafr.v8i1.12713

\begin{abstract}
This study investigates the underlying factors contributing to the International Financial Reporting Standards (IFRS) adoption in Nigeria. The diversity of responses to IFRS adoption is a phenomenon that requires empirical investigation to understand the reasons why some companies adopt IFRS other do not. Previous studies have investigated preparers of financial statements' compliance with IFRS. However, there is a dearth of research on the influence of cultural factors on IFRS adoption. Little has heretofore has been done to examine cultural variables as determinants of IFRS adoption. This study applies a self-administered survey instrument to elicit data from four major cities in Nigeria. The analysis involves applied logistic regression to estimate the relationship between the covariates and the companies'
\end{abstract}




\section{Macrothink}

International Journal of Accounting and Financial Reporting ISSN 2162-3082

decisions to adopt IFRS. The results indicate companies' professionalism, transparency, flexibility, secrecy, uniformity and statutory control are significant factors impacting IFRS adoption at different magnitudes. For example, a company that considers IFRS will increase the level of financial statements transparency is more likely to maintain some levels of secrecy. The study identifies that IFRS adoption can only be successful when accountants develop the relevant technical expertise in IFRS requirements prior to the implementation. Consequently, there is a need for more practical training in IFRS accounting valuation, recognition, measurement and disclosure of financial information to users of financial statements. The diversity in responses to IFRS adoption, where some companies adopt and others show resistance to IFRS requirements has been a phenomenon that requires empirical investigation to understand the rationale. Though some studies have investigated companies' compliance with accounting regulations in Nigeria, there is limited research on factors influencing IFRS adoption. A consequence is that efforts to come up with effective policies to enhance IFRS adoption and obtain compliance status for Nigerian companies are constrained. The objective is to contribute to initiatives aimed at assuring foreign investors of reliability of IFRS financial statements prepared by Nigerian companies.

Keywords: IFRS Adoption in Nigeria, Accounting values, Compliance, Regulation, Accounting practice

\section{Introduction}

Adoption of International Financial Reporting Standards (IFRS) became an important topic of interest after 1973 when variation in accounting practices and financial information asymmetry became sources of concern for accounting professionals and investors (Carlson, 1997). The concern grew as the globalisation of businesses continually evolved. Following the European Union (EU) implementation of IFRS, other countries such as Australia, New Zealand, Canada, South Africa and Nigeria have made changes to the Generally Accepted Accounting Principles (GAAPs). However, accounting researchers are concerned whether the implementation of IFRS, a product of a monopolistic accounting standard setter is the right decision towards a global accounting practice, since accounting is related to culture and culture is dynamic across jurisdictions and within countries (Borker, 2013b; Gray, 1988; Sunder, 2009).

In 2010, the Financial Reporting Council of Nigeria (FRC) implemented IFRS for all publicly accountable companies (Bakre \& Lauwo, 2016). The IFRS requirements led to the variations in the responses to the changes in accounting standards. Some companies adopted the IFRS while other did not. Consequently, some listed companies were deleted from the Nigerian Stock Exchange (NSE) due to non-compliance with the NSE X-compliance initiative. The $\mathrm{X}$-compliance report is the NSE initiative to ensure that listed companies comply with the requirements for listing on the stock exchange, including compliance with the accounting standards (Nigeria Stock Exchange, 2013).

Non-listed companies were also required to adopt IFRS effective from January 2013 (Madawaki, 2012). The requirement for non-listed companies in Nigeria to adopt IFRS is one of the uncommon accounting regulations among the IFRS jurisdictions. However, IFRS can 
be adopted for different purposes, especially for companies that aim to be listed on an international stock exchange (Nobes, 2008; Street \& Bryant, 2000; Street, Gray, \& Bryant, 1999).

International Financial Reporting Standards implementation in Nigeria resulted in two outcomes, namely IFRS adoption and non-adoption. The dichotomous reaction to IFRS adoption in Nigeria is contrary to the FRC purpose of implementing IFRS. In other words, IFRS were implemented to bring economic benefits to companies in Nigeria. The non-compliance with IFRS adoption led to the FRC warnings of sanctions, deletion of companies from the NSE and, as an extreme measure, deregistration from the Registrar of Companies in Nigeria.

However, the factors that influence the variability in the decisions to adopt IFRS are not well understood. Gray (1988) discussed the influence of cultural factors on accounting practice. Borker (2013b) also suggests that cultural factors are determinants of IFRS adoption. There is a dearth of knowledge on the extent to which these cultural variables influence companies' decisions to adopt IFRS.

This study aims to identify the significance of cultural factors on IFRS adoption among publicly accountable companies in Nigeria. The findings are discussed with reference to the impact of culture on the accounting system. This research is expected to contribute to our understanding of the factors inhibiting or enhancing IFRS adoption. The sections that follow include the theoretical background, followed by the data and methodology in section 3 , the empirical results in section 4 and the conclusion and implications of the study in section 5 .

\section{Theoretical Background}

International accounting standards have been inductively and deductively researched by different scholars. In some cases, inductive and deductive research approaches were combined to investigate the factors contributing to international accounting standards adoption and the heterogeneous responses to changes in accounting systems (Deegan, 2006).

A number of theories address how companies respond to changes in accounting systems. For example, agency theory illustrates how company management selects and applies accounting standards to the managers' advantage, as opposed to providers of capital, stemming from the underlying benefits in management performance and compensation agreements. Unlike agency theory, legitimacy theory "is a generalised perception or assumption that the actions of an entity are desirable, proper, or appropriate within socially constructed norms, values, beliefs, and definitions" (Suchman, 1995, p. 574). Legitimacy theory elucidates how preparers of financial statements apply accounting standards to provide quality financial statements that represent the economic reality for stakeholders' financial information.

Other theories, such as positive and normative accounting theories which explain preparers of financial statements reactions to changes in accounting policies, are somewhat confined to cultural theory (Borker, 2013b; Deegan, 2006). For example, Borker (2013a) explained that a financial reporting environment with a professional accounting orientation will be more successful in IFRS adoption than countries with statutory control (Borker, 2013b, p. 174). 


\section{MlMacrothink}

International Journal of Accounting and Financial Reporting

ISSN 2162-3082

Therefore, the following sections explain the links between cultural theory and companies' responses to changes in the accounting system.

\subsection{Linking Cultural Theory with IFRS Adoption}

Gray (1988) uses Hofstede (1984) survey of the cultural orientation of countries to explain the influence of culture on the development of accounting systems. Hofstede (1984) theory demonstrates the connection of external environmental factors, ecological factors, economic factors and institutional consequences in value creation. Hofstede (1984) stated that cultural dimensions influence the development of an organisational culture, in this case, the development of accounting systems. Borker (2013b) used Gray (1988) accounting theory to develop a framework to explore the opportunities and challenges in IFRS adoption.

The Hofstede cultural dimensions were developed from the "eclectic analysis of data, based on theoretical reasoning and correlation analysis" of survey data (Hofstede, 1984, p. 39). Cultural orientation was illustrated from 116,000 questionnaires from seventy countries with over 60,000 respondents. Four dimensions were developed and assigned to each of the countries, linking the dimensions with the demographic, geographic, economic and political factors of a country (Soares, Farhangmehr, \& Shoham, 2007).

Gray (1988) uses Hofstede dimensions (see Figure 1) to illustrate how the national environment can influence accounting systems. Gray extends Hofstede model to investigate the relationship between culture and accounting system. Gray developed four accounting value dimensions using accounting literature and theoretical reasoning. Gray discussed the impact of national culture on accounting practices and the type of accounting system that may exist in different national environments as illustrated in Figure 2. Gray (1988) identified professionalism, statutory control, conservatism, optimism, secrecy, transparency, uniformity and flexibility as determinants of accounting systems. 


\section{Macrothink \\ International Journal of Accounting and Financial Reporting

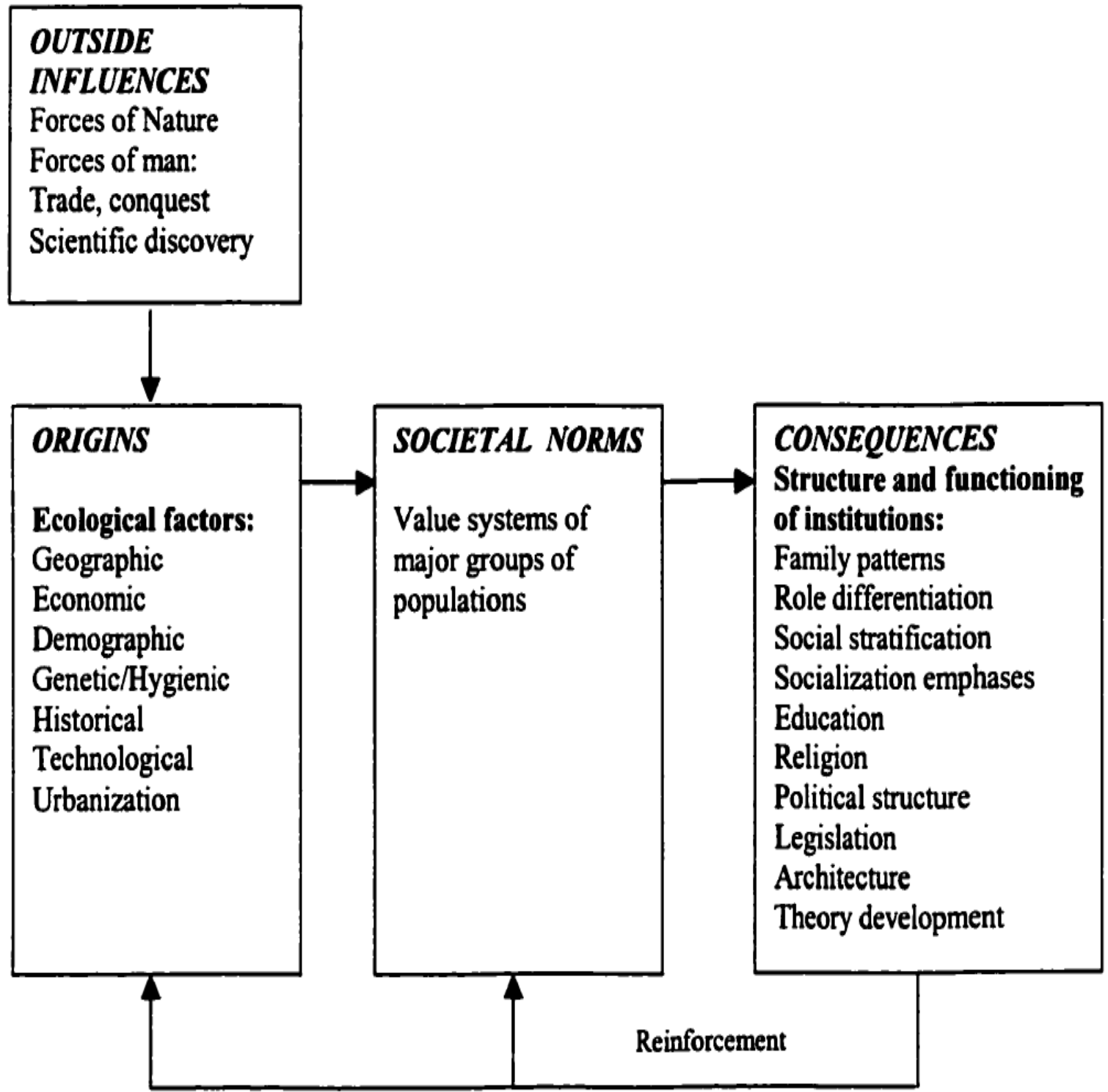

Figure 1. Culture, Societal Values and Consequences

Source: Hofstede (1984 p. 27)

Borker (2013b) suggested that Gray (1988) cultural dimensions can be used as a baseline to investigate the factors contributing to IFRS adoption among companies. This indicates a company accounting orientation can be identified and compared to the IFRS profile to understand the likelihood of IFRS adoption. The relationship between the companies' cultural factors and IFRS adoption are discussed in the following sections. 


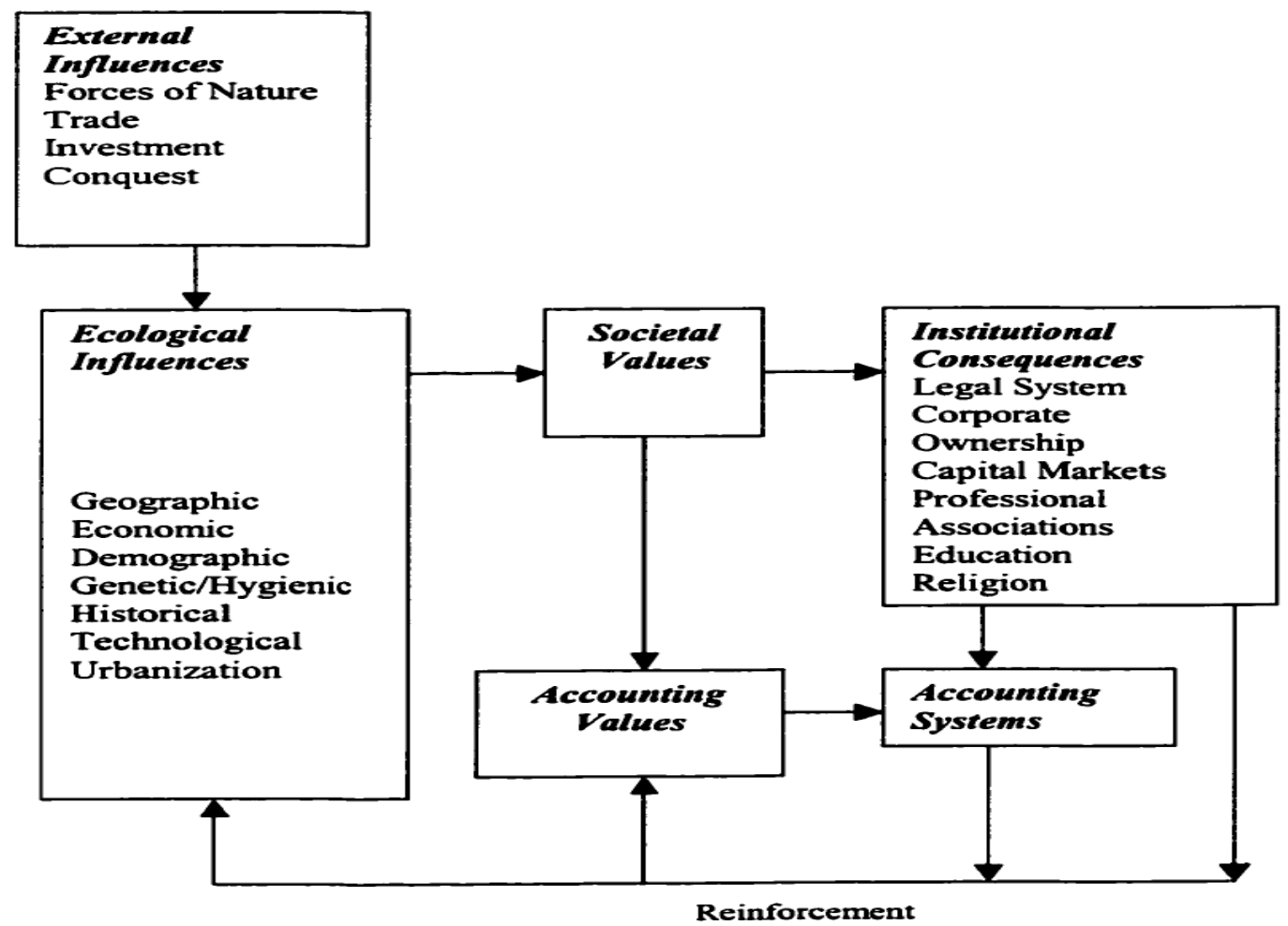

Figure 2. Culture, Societal Values and Accounting System

Source: Gray (1988, p. 7)

\subsubsection{Professionalism versus Statutory Control}

Professionalism versus statutory control indicates the use of professional judgment to determine accounting values rather than compliance with strict statutory prescriptions. In other words, this dimension has to do with a culture that uses self-judgement to determine accounting values versus a culture that prefers statutory prescription for accounting practice (Borker, 2013b; Gray, 1988). It is widely believed to be the motive for developing IFRS such that preparers of financial statements are able to use their professional knowledge of accounting to determine what accounting values are (Deegan, 2006; Nobes, 2008; Nobes \& Paker, 2012). The professionalism versus statutory control view is logical and consistent with Pricope (2016) identification of a hypothesis to empirically test impact of the relationship between professionalism and statutory control on IFRS adoption.

H1: The higher a company ranks in terms of professionalism and the lower it ranks in terms of statutory control, the more highly it will rank in terms of IFRS adoption.

\subsubsection{Conservatism versus Optimism}

Conservatism versus optimism explains the cautious behaviour of financial statement preparers in accounting measurement due to unknown future consequences. This is consistent with an earlier study by Watts \& Zimmerman (1978) about political cost and fear of utility cost of assets. This dimension was found to be strongly significant with Hofstede (1984) 
uncertainty avoidance. In an environment of uncertainty where the future is difficult to predict, conscious measurement and reporting of accounting values follow the conservative dimension of a company's accounting system (Gray, 1988; Watts \& Zimmerman, 1986). In contrast, optimism about future economic benefits associated with complying with certain accounting standards could lead to positive decisions on a company's compliance. Following the link between conservatism versus optimism and accounting systems, it is important to examine the empirical relationship between these variables and IFRS adoption. Therefore, these cultural dimensions are tested as follows:

H2: The higher a company ranks in terms of optimism and the lower it ranks in terms of conservatism the more highly it will rank in terms of IFRS adoption.

\subsubsection{Secrecy versus Transparency}

Secrecy versus transparency explains the confidentiality in accounting disclosure as opposed to transparency. The motivations for this behaviour are best explained in the Watts \& Zimmerman (1978) study on the increasing and decreasing behaviour of accountants for higher or lower accounting ratios and profit signaling.

One of the reasons IFRS were implemented in Nigeria was to ensure transparency in the financial statements. This is intended to give investors the confidence on the reliability of the financial statements from Nigerian companies (Madawaki, 2012). Given the level of economic development in Nigeria and possible political interference in the accounting system, it is assumed that the presence of secrecy would be expected in this environment. (Amenkhienan, 1986; Chimobi, 2016; Otto \& Ukpere, 2016). Considering these assumptions, it is reasonable to expect that secrecy and transparency to impact companies IFRS adoption. Therefore, the influence of secrecy and transparency on IFRS adoption is tested as follows:

H3: The higher a company ranks in terms of transparency and the lower it ranks in terms of secrecy the more highly it will rank in terms of IFRS adoption.

\subsubsection{Uniformity versus Flexibility}

Uniformity versus flexibility explains a preference for uniform accounting standards between companies and the application of prescribed accounting standards over time as opposed to flexibility. Flexibility is a preference for the application of accounting standards on an individual basis according to the circumstances of the financial transactions. If companies in Nigeria, resist IFRS adoption that ensures flexibility in terms of recognition, measurement and disclosure, a uniform accounting system is therefore expected to be the best accounting practice among Nigerian companies. This study empirically tests the extent uniformity and flexibility impacts companies IFRS adoption as follows:

H4: The higher a company ranks in terms of flexibility and the lower it ranks in terms of uniformity the more highly it will rank in terms of IFRS adoption.

\section{Methodology and Data}

The sampling frame covered companies in Nigeria. A random sample was applied to select publicly accountable companies. The sample included listed and non-listed companies. 


\section{MlMacrothink}

International Journal of Accounting and Financial Reporting ISSN 2162-3082 2018, Vol. 8, No. 1

The total listed companies in Nigeria as of September 2013 were 202 (International Monetary Fund, 2013). However, the exact number of non-listed companies that are active in Nigeria could not be determined accurately. Therefore, the unknown number of registered companies in Nigeria made it impossible to determine the population of non-listed companies. Owing to the practical difficulties in determining the sample size for the study, Anderson, Sweeney, Williams, Camm, \& Cochran (2016) and Cochran (1963) sample estimation technique was applied to estimate the minimum number of companies required to complete the questionnaires. The questionnaires were completed by the companies' Chief Financial Officers (CFO) and senior accounting staff responsible for the accounting systems.

Names and addresses of listed companies were extracted from the NSE website. The names of non-listed companies were obtained from the Directorate of Accounting Standards for the Private Sector at the FRC head office in Ikeja, Lagos Nigeria. The survey was conducted from November 2014 to January 2015.

The companies' cultural traits questions consisted of five-point Likert scales $(1=$ strongly disagree" and 5 = "strongly agree") while multiple choice questions were used to elicit data about the companies' characteristics based on previous studies (Chanchani \& Willett, 2004; Guerreiro, Rodrigues, \& Craig, 2012; Jones \& Higgins, 2006).

Some previous studies such as Shiab (2003), Barde (2009), Clements, Neill, and Stovall (2010), Zakari (2014) and Faraj and Firjani (2014) found company size, ownership structure, audit type and company listing status to influence IFRS adoption. Thus, these factors apply to this model as control variables. The independent and control variables including the priori signs are presented in Table 1.

Table 1. Definition of the Variables (for the Logit Model)

\begin{tabular}{llc}
\hline \multicolumn{1}{c}{ Variables } & \multicolumn{1}{c}{ Description } & $\begin{array}{c}\text { Priori } \\
\text { Sign }\end{array}$ \\
\hline FLEX & Flexibility (summated scale) (Note 1) & + \\
\hline TRANS & Transparency (summated scale) & + \\
\hline$S T A T$ & Statutory control (summated scale) & - \\
\hline OPT & Optimism (summated scale) & + \\
\hline PROF & Professionalism (summated scale) & + \\
\hline$U N I F$ & Uniformity (summated scale) & - \\
\hline CONS & Conservatism (summated scale) & - \\
\hline$S E C$ & Secrecy (summated scale) & + \\
\hline$A U D \_T Y P$ & Auditor Type (If the company external auditor is international, 0 otherwise) & + \\
\hline COM_SIZE & Company Size (1 if the number of shareholders is greater than 10, 0 otherwise & + \\
\hline COM_LIS_STA & Comp than 10 shareholders) & + \\
\hline OWN_TYP & Ownership (1 if the company is a non-family owned company, 0 otherwise) & + \\
\hline & & \\
\hline
\end{tabular}




\subsection{Empirical Model}

The study utilised logistic regression analysis. The discrete dependent variable Ifrs_Adop ${ }_{i t}$ measured whether a company adopted IFRS or had not adopted IFRS. The model dependent variable was based on the question asked in the questionnaire: Has your company complied with IFRS adoption? The model of the company's decision to adopt can be implicitly written under the general form:

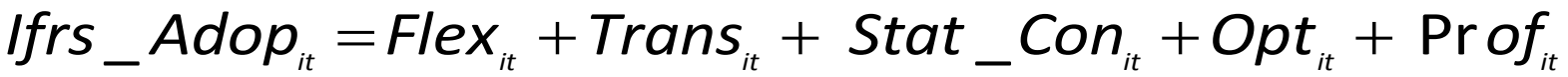

$$
\begin{aligned}
& + \text { Unif }_{i t}+\text { Cons }_{i t}+\operatorname{Sec}_{i t} \text { ? Aud_Typ } p_{i t}+\text { Com_Siz }_{i t}+ \\
& \text { Own_Typ } i t+\text { Com_Lis_Sta } i t+\varepsilon_{i t}
\end{aligned}
$$

An Exploratory Factor Analysis (EFA) was utilised to extract similar factors and scale down a large number of items and the scores of the items representing each construct were then averaged. Following this, we used the mean values of the variables in the logistic regression analysis.

\section{Empirical Results}

The empirical model on how company's cultural factors impact IFRS adoption is based on eight factors solution. These include professionalism, statutory control, optimism, conservatism, transparency, secrecy, flexibility and uniformity obtained from the EFA. The results include the maximum likelihood (ML) estimates, $t$-values, the marginal effects and summary statistics of the model.

The descriptive statistics of the variables used in the model are shown in Table 2. On an average, each mean in the summated scale variables is between 3 and 4 while the control variables are between 0 and 0.5 .

Table 2. Descriptive Statistics of Model Variables

\begin{tabular}{lllll}
\hline Variables & Minimum & Maximum & Mean & Std. Deviation \\
\hline OPT & 1 & 5 & 3.449 & 0.322 \\
\hline FLEX & 1 & 5 & 3.321 & 0.791 \\
\hline TRANS & 1 & 5 & 3.979 & 0.432 \\
\hline STAT_CON & 1 & 5 & 3.426 & 0.978 \\
\hline PROF & 1 & 5 & 3.358 & 0.831 \\
\hline UNIF & 1 & 5 & 3.385 & 0.639 \\
\hline CONS & 1 & 5 & 3.138 & 0.575 \\
\hline SEC & 1 & 5 & 3.701 & 0.436 \\
\hline AUD_TYP & 0 & 1 & 0.326 & 0.437 \\
\hline COM_SIZE & 0 & 1 & 0.379 & 0.410 \\
\hline COM_LIS_STA & 0 & 1 & 0.366 & 0.482 \\
\hline OWN_TYP & 0 & 1 & 0.290 & 0.531
\end{tabular}




\section{Mll Macrothink}

International Journal of Accounting and Financial Reporting ISSN 2162-3082 2018, Vol. 8, No. 1

The Pearson $\mathrm{R}$ coefficients are presented in Table 3. The Pearson $\mathrm{R}$ coefficients appear to exhibit positive correlations between IFRS adoption and flexibility, professionalism, audit type, and companies listing status. Contrary to the study hypotheses, the correlation matrix indicates negative correlations between transparency, ownership structure, optimism and IFRS adoption. It is expected these factors would have positive relationships with IFRS adoption. However, the results indicate otherwise. Other factors included in the study are consistent with the a priori description of the cultural factors.

Table 3. Correlation Matrix for the Companies' Cultural Model Variables

\begin{tabular}{|c|c|c|c|c|c|c|c|c|c|c|c|c|c|}
\hline \multicolumn{14}{|c|}{. corr } \\
\hline & ifrs_a p p & opt & flex & trans & stat_Con & prof & unif & cons & $\mathrm{sec}$ & aud_typ & com_size & com_li a & own_typ \\
\hline IFRS_ADOP & 1 & & & & & & & & & & & & \\
\hline$O P T$ & -0.0149 & 1 & & & & & & & & & & & \\
\hline FLEX & 0.4048 & 0.0142 & 1 & & & & & & & & & & \\
\hline STAT_CON & -0.101 & -0.0321 & -0.0321 & 0.037 & 1 & & & & & & & & \\
\hline PROF & 0.4004 & 0.0324 & 0.0312 & 0.0424 & -0.112 & 1 & & & & & & & \\
\hline$U N I F$ & -0.3234 & -0.1916 & -0.0934 & 0.2079 & 0.2402 & 0.1739 & 1 & & & & & & \\
\hline CONS & -0.007 & -0.0028 & 0.0032 & -0.0639 & 0.0103 & -0.0089 & -0.0288 & 1 & & & & & \\
\hline COM_LIS_STA & 0.6002 & -0.0797 & 0.2976 & -0.1219 & 0.0163 & -0.1362 & -0.1773 & 0.0225 & -0.1856 & 0.1036 & -0.1986 & 1 & \\
\hline$O W N \_T Y P$ & -0.5593 & -0.0268 & -0.2526 & 0.0318 & 0.0433 & 0.0994 & 0.177 & -0.0426 & 0.1474 & -0.1601 & 0.0849 & -0.3193 & 1 \\
\hline
\end{tabular}

The logit results presented in Table 4 identified the cultural factors influence on decisions to adopt IFRS among the Nigerian listed and non-listed companies. The significant factors include FLEX, TRANS, STAT_CON, PROF, UNIF and SEC. Further, only the AUD_TYP and $O W N \_T Y P$ are statistically significant among the control variables.

\subsection{Flexibility and Uniformity Dimension}

Table 4 shows the flexibility (FLEX) coefficient is positive and statistically significant at 1 percent level. This implies that the more flexible a company's accounting system is, in relation to transactionary activities and financial reporting, the greater the probability that the company will adopt IFRS. Consequently, companies that have accounting systems that are less flexible will consider IFRS non-adoptable.

Souza, Botinha, Silva, and Lemes (2015) state that the flexibility in IFRS policies impacts IFRS adoption. However, flexibility in accounting practice could be a motivating factor for 
some companies, while a prohibitive factor to others that have experiences in uniform accounting practice. This is most likely when the companies have conservatively applied uniform accounting standards prior to IFRS adoption (Luo, 2016).

In terms of the extent of the flexibility factor that impact on IFRS adoption, the result indicates a unit change in the company's flexibility in accounting practice will most likely increase IFRS adoption by 3.9 percent (see Table 4). Flexibility in accounting practice implies applying a particular accounting measurement method in a given situation related to the objective of the financial report instead of following a prescribed method that does not allow changes in financial reporting. Alternatively, flexibility factor can be explained in terms of applying discretionary recognition, measurement and disclosure in financial reporting (Hann et al., 2007; Kaplan, 2012).

Table 4. Logit Results of the Influence of Organisational Culture on IFRS Adoption

\begin{tabular}{|c|c|c|c|c|c|}
\hline Cultural Factors & Coef. & Std. Err. & T-Statistics & $P>|z|$ & $\begin{array}{l}\text { Marginal } \\
\text { Effects }\end{array}$ \\
\hline$O P T$ & -0.048 & 0.095 & -0.510 & 0.609 & -0.004 \\
\hline FLEX & $0.435^{*}$ & 0.078 & 5.570 & 0.000 & 0.039 \\
\hline TRANS & $-0.099 * *$ & 0.045 & -2.220 & 0.026 & -0.009 \\
\hline STAT_CON & $-0.163 * *$ & 0.070 & -2.340 & 0.019 & -0.015 \\
\hline PROF & $6.082 *$ & 0.888 & 6.850 & 0.000 & 0.502 \\
\hline UNIF & $-0.222 *$ & 0.063 & -3.500 & 0.000 & -0.020 \\
\hline CONS & -0.005 & 0.071 & -0.080 & 0.939 & 0.030 \\
\hline$S E C$ & $-0.288 *$ & 0.065 & -4.450 & 0.000 & -0.026 \\
\hline$A U D \_T Y P$ & $2.239 *$ & 0.546 & 4.100 & 0.000 & 0.143 \\
\hline COM_SIZE & -0.902 & 0.605 & -1.490 & 0.136 & -0.066 \\
\hline COM_LIS_STA & -0.037 & 0.062 & -0.590 & 0.553 & -0.003 \\
\hline$O W N \_T Y P$ & $-3.714 *$ & 0.482 & -7.710 & 0.000 & -0.392 \\
\hline _CONS & $5.491 * *$ & 2.179 & 2.520 & 0.012 & \\
\hline Number of observation & 519 & & & & \\
\hline Log Likelihood function & 92.812 & & & & \\
\hline Chi squared & $252.94 * * *$ & & & & \\
\hline Prob > chi 2 & 0.001 & & & & \\
\hline df & 10 & & & & \\
\hline Pseudo $\mathrm{R}^{2}$ & 0.733 & & & & \\
\hline Hosmer-Lemeshow's & 2.48 & & & & \\
\hline PCP & 0.783 & & & & \\
\hline
\end{tabular}

$*, * *, * * *$ denote statistically significant at 1,5 and 10 percent level. ${ }^{\text {NS }}$ indicates not significant. 


\section{Macrothink}

International Journal of Accounting and Financial Reporting ISSN 2162-3082

There is no doubt accounting practices are determined by organisational culture (Mulawarman, 2012), but the development of IFRS in the globalisation of accounting practices suggest a change from uniform to flexible approach in financial reporting (Jermakowicz, 2004). The Nigerian accounting system has been practiced as a uniform financial reporting system where the policies and procedures are strictly followed. Variability in financial reporting based on the differences in financial transactions appears to be given secondary consideration.

The Uniformity (UNIF) coefficient in accounting practice is negative and significant at the 1 percent level. The results show that a unit increase in the companies' strictly standardised accounting system, has the likelihood to decrease the level of IFRS adoption by 2 percent. Uniformity in accounting is one of the companies' cultural factors contributing to IFRS non-adoption. The impact of uniformity is significant and consists of -0.020 marginal effect.

Uniformity in accounting practice can be interpreted in two ways i.e. from relatively strict inter-company to inter-temporal uniformity (Gray, 1988). The interpretation of the uniformity effects on IFRS adoption is based on the Gray Framework. Under uniformity, accounting practice is perceived to be uniform across the companies being regulated in the same business environment. The result shows the contrast between the companies' attitude for strict control in their accounting practices and companies' discretion in recognition, measurement and accounting disclosure. This finding is consistent with a previous study where uniformity in accounting practice was found to be associated with IFRS non-adoption. For example, Salewski and Zülch (2015) reported that German listed companies were challenged by the lack of uniformity in IAS 19. The companies were found to be resistant to changes from the GAAP accounting regime to IFRS.

There is support for uniform accounting system in eliminating the "moral hazard problem" in financial reporting (Dye \& Verrecchia, 1995; Hann et al., 2007, p. 113). The lack of value relevance of financial statements from uniform accounting practice shows the need to change from uniform to more qualitative accounting system. Consequently, accounting value should be determined based on situational analysis of financial transactions (Nobes \& Stadler, 2015). Such analysis which is part of IFRS orientation poses a challenge to companies with limited familiarity with qualitative analysis and inadequate analytic tools to determine accounting values in some business environments such as Nigeria.

\subsection{Transparency versus Secrecy Dimension}

The transparency (TRANS) coefficient is negative and significant at the 5 percent level suggesting that the more transparent the IFRS financial statements, the greater the likelihood companies will not adopt IFRS. Transparency in financial reporting implies the companies' willingness to disclose their accounting transactions to the users of financial information (see Table 4).

The logit results show that transparency in financial reporting has a negative association with IFRS adoption. The impact of transparency is relatively high. Increase in IFRS financial statements level of transparency appears to decrease the likelihood of IFRS adoption. 


\section{Mll Macrothink}

International Journal of Accounting and Financial Reporting

ISSN 2162-3082

2018, Vol. 8, No. 1

The direction of the a priori hypothesis sign for transparency is different from the estimated result which suggests that the companies are concerned about the level of transparency in their financial statements. While it would be expected that transparency factor would positively influence financial statements preparers' decisions to adopt IFRS (Borker, 2013a, 2013b; Gray, 1988; Kaplan, 2012; Nurunnabi, 2016; Tsalavoutas \& Dionysiou, 2014), the finding from this study indicates otherwise.

For example, Gray (1988) found that preparers of financial statements are more open and publicly accountable about their financial information in some business environments than others. In that case, transparency should determine the likelihood of adopting different types of accounting standards. Borker (2013a, p. 682) also states that IFRS adoption "increases stability, stewardship, accountability and transparency at both the company and government institutional level". According to this view, companies are more likely to adopt IFRS because of the perception that IFRS enhances transparency in financial reporting. However, the negative correlation and significance of transparency indicates that the companies in this study are less transparent, less open and have a weaker publicly accountable approach which is different from IFRS profile (Borker, 2013a). The finding also differs from Tsalavoutas and Dionysiou (2014) which reported that IFRS adoption is associated with companies level of transparency, meaning that non-adopters are less likely to be transparent in their financial reporting.

One of the reasons for IFRS adoption in Nigeria is the perception that IFRS increases financial reporting transparency (Iyoha \& Oyerinde, 2010; Madawaki, 2012; Odia \& Ogiedu, 2013; Osemeke \& Adegbite, 2016). In the former Central Bank of Nigeria report on IFRS implementation, it was stated that IFRS adoption is "expected to enhance market discipline, and reduce uncertainties which limit the risk of unwarranted contagion" (Sanusi, 2010, p. 15). However, the implementation of IFRS for the purpose of transparency in financial reporting is a significant challenge to Nigerian companies due to the individualism orientation of the business environment as classified in Hofstede (2001).

The negative significance of transparency in the model appears to confirm the culture of secrecy in commercial transactions exhibited by preparers of financial statements (Zadek, Evans, \& Pruzan, 2013). Adoption of IFRS would thus pose a significant challenge to Nigerian companies.

The secrecy $(S E C)$ coefficient is negative and significant at the 1 percent level. The result implies that the greater the companies are concerned about disclosure of financial information to stakeholders, the less likelihood they will adopt IFRS.

Secrecy involves companies maintaining strict confidentiality of their financial information. It can vary depending on the ownership of the companies and the management system which is similarly linked to concerns about political cost, labour union agitation and contractual covenants (Cannizzaro \& Weiner, 2015; Khalil \& Simon, 2014; Watts \& Zimmerman, 1986).

Vashishtha (2014) found that companies are more interested in secrecy and maintain some reservation in adopting certain accounting standards when a violation of contractual 
covenants occurs. Further, an earlier study by Wallace (1987) reported how management type determines whether a company maintains secrecy in financial statements and how the Nigerian socioeconomic environment encourages such practice owing to the weak legal system.

The result indicates that a change in the companies' secrecy in disclosing financial information will change the likelihood that the companies will not adopt IFRS. The significance of the secrecy coefficient in this study can be interpreted as "a preference for confidentiality and the restriction of disclosure of financial information to those who are closely involved with its management as opposed to a more transparent, open, and publicly accountable approach" (Doupnik \& Perera, 2009, p. 41). The result is similar to Barth, Landsman, and Lang (2008) where companies that have adopted IFRS were found to be less confidential in their financial statements than non-adopters. The finding from Barth et al. (2008) further shows that companies applying IFRS exhibit less earnings management, more timely loss recognition and provide more value relevant information than IFRS non-adopters. It indicates the divergence between IFRS and companies' likelihood to maintain some level of confidentiality in their financial reporting.

The significance of secrecy further implies that the companies' preferred accounting standards are inconsistent with IFRS.

\subsection{Statutory Control versus Professionalism Dimension}

The statutory control (STAT_CON) coefficient is negative and significant at the 5 percent level. Based on the marginal effects, the result indicates a change in the compliance with rigid legal requirements has the likelihood to decrease IFRS adoption. The negative coefficient of statutory control indicates challenges for companies that have developed accounting systems as compliance with rigid legal requirements and legislative control in contrast to professional judgment and self-regulation. The result confirms Borker (2013b) statement of the unfavourable profile of statutory control accounting practice and IFRS adoption.

Companies whose accounting systems depend on accounting regulators' guidelines and prescribed methods for recognition, measurement, and disclosure are more likely to resist IFRS adoption. International Financial Reporting Standards are known for their professionalism rather than statutory control.

Strict methods and detailed guidelines for preparing financial statements are not often the objectives of IFRS (De George, Ferguson, \& Spear, 2012; Schipper, 2003). For example, IFRS allow companies to use professional judgment in certain situations when assets and liabilities are valued, specifically assets that have no comparable market price.

Borker $(2012,2013 b)$ found that in a business environment where companies practiced accounting as compliance with statutory requirements which can otherwise be interpreted as rules or strict legal requirements, IFRS adoption is unfavourable. One of the reasons IFRS would be viewed as unfavourable among companies that practice accounting as statutory requirements may be due to the qualitative characteristics of IFRS accounting principles 


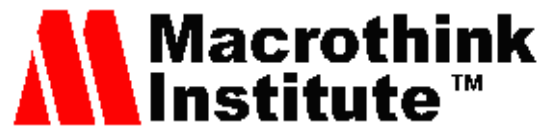

International Journal of Accounting and Financial Reporting ISSN 2162-3082

including the requirements for professional judgment (Borker, 2016b; Botzem, 2014; Perera, Cummings, \& Chua, 2012). Therefore, the adoption of IFRS is a challenge to Nigerian companies because the previous GAAP regime was a rules-based accounting system. (Ikpefan \& Akande, 2012; Uche, 2002)

Professionalism focuses on the financial preparers' professional judgment in recognition, measurement, and disclosure of financial information (Askary, 2006; Houqe, Monem, Tareq, \& van Zijl, 2016; Perera et al., 2012). The professionalism (PROF) coefficient has a positive impact on IFRS adoption at the 1 percent level. It suggests that companies that apply professional judgment in determining accounting values are more likely to adopt IFRS. The marginal effect is 0.502 (see Table 4.3). It means that a change in the level of company's professionalism will increase the likelihood of IFRS adoption. Considering that IFRS adoption is very recent in Nigeria, the level of IFRS knowledge is very meagre.

The significance of professionalism coefficient indicates the likelihood of increasing IFRS adoption by cultivating more professionalism and deemphasizing statutory control.

The challenges faced in IFRS adoption by countries classified as highly professional in Hofstede (2001) have minimal impact on IFRS adoption (Chanchani \& Willett, 2004; Stent, Bradbury, \& Hooks, 2010; van Zij1 \& Bradbury, 2006). However, the correlation between professionalism and IFRS adoption in the empirical result is consistent with other studies, where professionalism is found to be associated with IFRS adoption (Barth et al., 2008; Hope, Kang, Thomas, \& Yoo, 2008; Houqe et al., 2016). For example, Houqe et al. (2016) found a positive relationship between professionalism and IFRS adoption. This was attributed to consultancy services by the Big 4 audit firms that exhibit professionalism in determining what constitutes accounting values.

\subsection{Optimism versus Conservatism Dimension}

The optimism $(O P T)$ coefficient is insignificant, meaning that there is no sufficient evidence to conclude there is a relationship between the companies' optimism about future business opportunities and IFRS adoption. (see Table 4). The impact of conservative (CONS) accounting system is also insignificant. However, the direction of the coefficient shows that conservative accounting practice can hinder IFRS adoption. This is based on the negative coefficients of the conservatism factor.

The companies' ownership ( $\left.O W N \_T Y P\right)$ coefficient is positive and significant at the 1 percent level. The result indicates that non-family owned companies are more likely to adopt IFRS. Under ownership structure and IFRS adoption, it was discussed in Chen \& Nowland (2010) that companies that are not family owned are more likely to adopt transparent financial reporting frameworks such as IFRS than other types of ownership. Table 4.3 shows that ownership structure is likely to have some impact on IFRS adoption. The finding is consistent with a previous study which found that ownership structure influences companies' decisions to adopt IAS 41 (Gonçalves \& Lopes, 2014)

The audit type (AUD_TYP) coefficient is positive and significant at the 1 percent level, meaning that companies using international audit firms in Nigeria such as Deloitte, Ernst and 


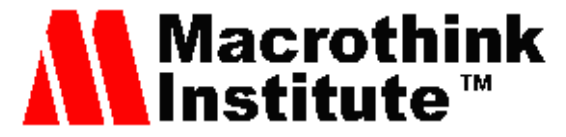

International Journal of Accounting and Financial Reporting

ISSN 2162-3082

2018, Vol. 8, No. 1

Young, KPMG and PricewaterhouseCoopers have a greater probability of IFRS adoption than companies that used local audit firms. The significance of audit firms on IFRS adoption confirms Souza et al. (2015) report on the impact of Big 4 audit firms on IFRS adoption. In the case of Nigeria, the Big 4 audit firms are considered as international audit firms.

\section{Implication and Conclusion}

Our study examined the effects of organisational culture on IFRS adoption among Nigerian companies. We empirically investigated the relationship between companies' willingness to adopt IFRS and cultural factors, consistent with Gray (1988) and Borker (2013a). The study also includes companies' characteristics in predicting the likelihood of IFRS adoption.

The results show that cultural factors and corporate characteristics are important factors in explaining the decisions by companies to adopt IFRS. The results of the study provide insights for accounting regulators and companies to improve financial reporting systems and enhance compliance with IFRS in the de facto and minimise de jure accounting practices. Further, the findings suggest new directions for international accounting researchers drawing from the negative relationship between transparency and IFRS adoption.

Previous studies showed that cultural factors do not influence IFRS adoption, but the company characteristics such as size influence the decisions by preparers of financial statements to adopt IFRS (Clements et al., 2010). After controlling for company size effect in the empirical model, this study identified significant relationships between a set of cultural factors and the companies' willingness to adopt IFRS.

Further, the study also confirms Perumpral et al. (2009) that culture is one of the obstacles to international accounting standards adoption. The study however, identified the aspects of cultural factors that influence IFRS adoption different from previous studies. Earlier studies stated the possible influence of culture on IFRS adoption without any specific reference to the aspect of culture that influences IFRS adoption (Faraj \& Firjani, 2014; Zakari, 2014). Based on our findings, not all aspects of culture positively or negatively impact IFRS adoption. For example, the literature believed that the greater transparency in IFRS financial statements the more likely companies will adopt IFRS (Guerreiro, 2012). The empirical results challenge this perception. The negative significance of transparency in this study implies that the impact of culture can vary depending on the financial reporting environment.

\section{Acknowledgement}

We would like to thank the students and computer centre operators who helped in administering the survey questionnaire in Lagos, Abuja and Benin City Nigeria. We also acknowledge all the research participants who completed the questionnaires.

\section{References}

Ahmed, K. (1996). Disclosure policy choice and corporate characteristics: A study of Bangladesh. Asia-Pacific Journal of Accounting, 3(1), 183-203. https://doi.org/10.1080/10293574.1996.10510493 


\section{MInstitute Macrothink $^{\text {Int }}$}

International Journal of Accounting and Financial Reporting ISSN 2162-3082

Ali, M. J. (2005). A Synthesis of Empirical Research on International Accounting Harmonization and Compliance with International Financial Reporting Standards. Journal of Accounting literature, 24, 1-52.

Amenkhienan, F. E. (1986). Accounting in Developing Countries: a framework for standard setting. UMI Research Press.

Anderson, D. R., Sweeney, D. J., Williams, T. A., Camm, J. D., \& Cochran, J. J. (2016). Statistics for Business \& Economics (13th ed.).

Askary, S. (2006). Accounting professionalism - a cultural perspective of developing countries. Managerial Auditing Journal, 21(1/2), 102-111. https://doi.org/10.1108/02686900610634784

Bakre, O. M., \& Lauwo, S. (2016). Privatisation and accountability in a "crony capitalist" Nigerian state. Critical Perspectives on Accounting 39, 45-58. https://doi.org/10.1016/j.cpa.2016.01.003

Barde, I., Magaji. (2009). An Evaluation of Accounting Information Disclosure in the Nigerian Oil Marketing Industry. PhD Thesis Bayero University, Nigeria.

Barth, M. E., Landsman, W. R., \& Lang, M. H. (2008). International accounting standards and accounting quality. Journal of Accounting Research, 46(3), 467-498. https://doi.org/10.1111/j.1475-679X.2008.00287.x

Borker, D. R. (2012). Accounting, culture, and emerging economies: IFRS in the BRIC countries. Journal of Business \& Economics Research, 10(5), 313. https://doi.org/10.19030/jber.v10i5.6983

Borker, D. R. (2013a). Accounting and Cultural Values: IFRS in 3G Economies. The International Business \& Economics Research Journal, 12(6), 671. https://doi.org/10.19030/iber.v12i6.7872

Borker, D. R. (2013b). Is There A Favorable Cultural Profile For IFRS?: An Examination and Extension of Gray's Accounting Value Hypotheses. International Business \& Economics Research Journal (IBER), 12(2), 167-178. https://doi.org/10.19030/iber.v12i2.7629

Borker, D. R. (2016a). Gauging the Impact of Country-Specific Values on the Acceptability of Global Management Accounting Principles. European Research Studies, 19(1), 149.

Borker, D. R. (2016b). Global management accounting principles and the worldwide proliferation of IFRS. The Business \& Management Review, 7(3), 258.

Botzem, S. (2014). Transnational standard setting in accounting: organizing expertise-based self-regulation in times of crises. Accounting, Auditing \& Accountability Journal, 27(6), 933-955. https://doi.org/10.1108/AAAJ-04-2013-1301

Cannizzaro, A. P., \& Weiner, R. J. (2015). Multinational investment and voluntary disclosure: Project-level evidence from the petroleum industry. Accounting, Organizations and Society, 42, 32-47. https://doi.org/10.1016/j.aos.2015.01.002 


\section{Macrothink}

International Journal of Accounting and Financial Reporting ISSN 2162-3082

Carlson, P. (1997). Advancing the harmonisation of international accounting standards: exploring an alternative path. The International Journal of Accounting, 32(3), 357-378. https://doi.org/10.1016/S0020-7063(97)90016-9

Chanchani, S., \& Willett, R. (2004). An empirical assessment of Gray's accounting value constructs. The International Journal of Accounting, 39(2), 125-154. https://doi.org/10.1016/j.intacc.2004.02.003

Chen, E. T., \& Nowland, J. (2010). Optimal Board Monitoring in Family-owned Companies: Evidence from Asia. Corporate Governance: An International Review, 18(1), 3-17. https://doi.org/10.1111/j.1467-8683.2009.00778.x

Chimobi, O. P. (2016). Government expenditure and national income: A causality test for Nigeria. European Journal of Economic and Political Studies, 2(2), 1-11.

Choi, F. D., \& Meek, G. K. (2010). International Accounting (7th ed.). Pearson Education Limited.

Clements, C. E., Neill, J. D., \& Stovall, O. S. (2010). Cultural diversity, country size, and the IFRS adoption decision. Journal of Applied Business Research (JABR), 26(2). https://doi.org/10.19030/jabr.v26i2.288

Cochran, W. (1963). Sampling Techniques. New York: John Wiley \& Sons.

De George, E. T., Ferguson, C. B., \& Spear, N. A. (2012). How much does IFRS cost? IFRS adoption and audit fees. The Accounting Review, 88(2), 429-462. https://doi.org/10.2308/accr-50317

Deegan, C. (2006). Financial accounting theory (2nd ed.). McGraw-Hill Irwin.

Doupnik, T., \& Perera, H. (2009). International Accounting (2nd ed.). McGra-Hill International.

Dye, R. A., \& Verrecchia, R. E. (1995). Discretion vs. uniformity: Choices among GAAP. Accounting Review, 389-415.

Faraj, S., \& Firjani, E. (2014). Challenges facing IASs/IFRS implementation by Libyan listed companies. Universal Journal of Accounting and Finance, 2(3), 57-63.

Gonçalves, R., \& Lopes, P. (2014). Firm-specific Determinants of Agricultural Financial Reporting. Procedia - Social and Behavioral Sciences, 110, 470-481. https://doi.org/10.1016/j.sbspro.2013.12.891

Gray, S. J. (1988). Towards a theory of cultural influence on the development of accounting systems internationally. Abacus, 24(1), 1-15. https://doi.org/10.1111/j.1467-6281.1988.tb00200.x

Guerreiro, M. (2012). Essays on the institutionalisation of a new accounting regime for unlisted companies in Portugal. PhD Thesis, Universidade do Minho. 


\section{Macrothink}

International Journal of Accounting and Financial Reporting ISSN 2162-3082

Guerreiro, M., Rodrigues, L.L., \& Craig, R. (2012). Voluntary adoption of International Financial Reporting Standards by large unlisted companies in Portugal - Institutional logics and strategic responses. Accounting, Organizations and Society, 37(7), 482-499. https://doi.org/10.1016/j.aos.2012.05.003

Hann, R. N., Lu, Y. Y., \& Subramanyam, K. (2007). Uniformity versus flexibility: evidence from pricing of the pension obligation. The Accounting Review, 82(1), 107-137. https://doi.org/10.2308/accr.2007.82.1.107

Hofstede, G. H. (1984). Culture's consequences: International differences in work-related values (Abridged ed., Cross-cultural research and methodology series). Beverly Hills: Sage Publications.

Hofstede, G. H. (2001). Culture's consequences: Comparing values, behaviors, institutions, and organizations across nations (2nd ed.). Thousand Oaks, Calif.: Sage Publications.

Hope, O.-K., Kang, T., Thomas, W., \& Yoo, Y. K. (2008). Culture and auditor choice: A test of the secrecy hypothesis. Journal of accounting and public policy, 27(5), 357-373. https://doi.org/10.1016/j.jaccpubpol.2008.07.003

Houqe, M. N., Monem, R. M., Tareq, M., \& van Zijl, T. (2016). Secrecy and the impact of mandatory IFRS adoption on earnings quality in Europe. Pacific-Basin Finance Journal, 40, 476-490. https://doi.org/10.1016/j.pacfin.2016.08.002

Ibrahim, M. A.-A. (2014). The challenges and opportunities of Iraq transitioning to international accounting standards with particular emphasis on accounting for oil. PhD Thesis, NOVA. The University of Newcastle's Digital Repository.

Ikpefan, O. A., \& Akande, A. (2012). International financial reporting standard (IFRS): Benefits, obstacles and intrigues for implementation in Nigeria. Business Intelligence Journal, 5(2), 299-307.

International Monetary Fund. (2013). Nigeria: Publication of Financial Sector Assessment Program Documentation Detailed Assessment of Implementation of IOSCO Objectives and $\begin{array}{lllll}\text { Principles of Securities Regulation. } & \text { Retrieved }\end{array}$ http://www.imf.org/external/pubs/ft/scr/2013/cr13144.pdf

Iyoha, F., \& Oyerinde, D. (2010). Accounting infrastructure and accountability in the management of public expenditure in developing countries: A focus on Nigeria. Critical Perspectives on Accounting, 21(5), 361-373. https://doi.org/10.1016/j.cpa.2009.06.002

Jarvenpaa, S. L., \& Majchrzak, A. (2016). Interactive self-regulatory theory for sharing and protecting in interorganizational collaborations. Academy of Management Review, 41(1), 9-27. https://doi.org/10.5465/amr.2012.0005

Jermakowicz, E. K. (2004). Effects of adoption of international financial reporting standards in Belgium: the evidence from BEL-20 companies. Accounting in Europe, 1(1), 51-70. https://doi.org/10.1080/0963818042000270811 


\section{MlMacrothink}

International Journal of Accounting and Financial Reporting ISSN 2162-3082

Jones, S., \& Higgins, A. D. (2006). Australia's switch to international financial reporting standards: a perspective from account preparers. Accounting \& Finance, 46(4), 629-652. https://doi.org/10.1111/j.1467-629X.2006.00186.x

Kaplan, R. (2012). Building and Managing E-Book Collections A How-To-Do-It Manual for Librarians (A How-To-Do-It Manual for Librarians). Chicago: American Library Association.

Khalil, M., \& Simon, J. (2014). Efficient contracting, earnings smoothing and managerial accounting discretion. Journal of Applied Accounting Research, 15(1), 100-123. https://doi.org/10.1108/JAAR-06-2012-0050

Luo, G. Y. (2016). Accounting Conservatism, Market Liquidity and Informativeness of Asset Price: Implications on Mark to Market Accounting. Journal of Applied Finance \& Banking, 3(1), 177-190.

Madawaki, A. (2012). Adoption of International Financial Reporting Standards in developing countries: the case of Nigeria. International Journal of Business and Management, 7(3), 152. https://doi.org/10.5539/ijbm.v7n3p152

Mulawarman, A. (2012). Accounting in the Madness Vortex of Neoliberal IFRS-IPSAS: A Criticism of IAS 41 and IPSAS 27 on Agriculture. Paper presented at the International Conference of Critical Accounting.

Nigeria Stock Exchange. (2013). The NSE Delists Companies from Daily Official List. Retrieved from http://www.nse.com.ng/MarketNews/Press\%20Releases/NSE\%20Delists

Nobes, C. (2008). Accounting classification in the IFRS era. Australian Accounting Review, 18(3), 191-198. https://doi.org/10.1111/j.1835-2561.2008.0024.x

Nobes, C., \& Paker, R. (2012). Comparative International Accounting (12th ed.). Pearson Education.

Nobes, C., \& Stadler, C. (2015). The qualitative characteristics of financial information, and managers' accounting decisions: evidence from IFRS policy changes. Accounting and Business Research, 45(5), 572-601. https://doi.org/10.1080/00014788.2015.1044495

Nurunnabi, M. (2016). The Role of the State and Accounting Transparency: IFRS Implementation in Developing Countries. Routledge.

Odia, J., \& Ogiedu, K. (2013). IFRS Adoption: Issues, Challenges and Lessons for Nigeria and other Adopters. Mediterranean Journal of Social Sciences, 4(3), 389. https://doi.org/10.5901/mjss.2013.v4n3p389

Olamide, J. O., \& Ajibade, A. T. (2016). Evolution of Accounting Standards in Nigeria: A Historical Perspective. Evolution, 2(8).

Oliver, C. (1991). Strategic Responses to Institutional Processes. The Academy of Management Review, 16(1), 145-179. https://doi.org/10.5465/AMR.1991.4279002 


\section{М Macrothink}

International Journal of Accounting and Financial Reporting ISSN 2162-3082

Osemeke, L., \& Adegbite, E. (2016). Regulatory multiplicity and conflict: Towards a combined code on corporate governance in Nigeria. Journal of Business Ethics, 133(3), 431-451. https://doi.org/10.1007/s10551-014-2405-3

Otto, G., \& Ukpere, W. (2016). Exports and economic growth in Nigeria. Annals of" Spiru Haret". Economic Series, 13(3), 37-50.

Perera, H., Cummings, L., \& Chua, F. (2012). Cultural relativity of accounting professionalism: Evidence from New Zealand and Samoa. Advances in Accounting, 28(1), 138-146. https://doi.org/10.1016/j.adiac.2012.03.006

Perumpral, S. E., Evans, M., Agarwal, S., \& Amenkhienan, F. (2009). The evolution of Indian accounting standards: Its history and current status with regard to International Financial Reporting Standards. Advances in Accounting, 25(1), 106-111. https://doi.org/10.1016/j.adiac.2009.02.003

Pricope, C. F. (2016). The role of institutional pressures in developing countries. Implications for IFRS. Theoretical and Applied Economics, 22 (2 (607), Summer), 27-40.

Salewski, M., \& Zülch, H. (2015). Discretion in the accounting for defined benefit obligations-an empirical analysis of German IFRS statements. Journal of Pension Economics and Finance, 14(03), 266-292. https://doi.org/10.1017/S1474747214000249

Sanusi, L. S. (2010). Growth prospects for the Nigerian economy. Convocation lecture delivered at the Igbinedion University, Okada, Edo State, Nigeria. Retrieved from http://www.cenbank.gov.ng/out/speeches/2010/gov_convocation_lecture-igbinedion-universi ty-okada_2010.pdf

Schipper, K. (2003). Principles-based accounting standards. Accounting Horizons, 17(1), 61-72. https://doi.org/10.2308/acch.2003.17.1.61

Scott, W. R. (2001). Institutions and organizations (2nd ed.). Thousand Oaks, Calif.: Sage Publications.

Shammari, B., Brown, P., \& Tarca, A. (2008). An investigation of compliance with international accounting standards by listed companies in the Gulf Co-Operation Council member states. The International Journal of Accounting, 43(4), 425-447. https://doi.org/10.1016/j.intacc.2008.09.003

Shiab, M. (2003). Financial consequences of IAS adoption: the case of Jordan. PhD Thesis, Newcastle University.

Soares, A. M., Farhangmehr, M., \& Shoham, A. (2007). Hofstede's dimensions of culture in international marketing studies. Journal of Business Research, 60(3), 277-284. https://doi.org/10.1016/j.jbusres.2006.10.018

Souza, F. E. A. d., Botinha, R. A., Silva, P. R., \& Lemes, S. (2015). Comparability of Accounting Choices in Future Valuation of Investment Properties: An Analysis of Brazilian 
and Portuguese Listed Companies. Revista Contabilidade \& Finanças, 26(68), 154-166. https://doi.org/10.1590/1808-057x201500580

Stent, W., Bradbury, M., \& Hooks, J. (2010). IFRS in New Zealand: effects on financial statements and ratios. Pacific accounting review, 22(2), 92-107. https://doi.org/10.1108/01140581011074494

Street, D. L., \& Bryant, S. M. (2000). Disclosure Level and Compliance with IASs: A Comparison of Companies With and Without U.S. Listings and Filings. The International Journal of Accounting, 35(3), 305-329. https://doi.org/10.1016/S0020-7063(00)00060-1

Street, D. L., Gray, S. J., \& Bryant, S. M. (1999). Acceptance and Observance of International Accounting Standards: An Empirical Study of Companies Claiming to Comply with IASs. The International Journal of Accounting, 34(1), 11-48. https://doi.org/10.1016/S0020-7063(99)80002-8

Suchman, M. C. (1995). Managing Legitimacy: Strategic and Institutional Approaches. The Academy of Management Review, 20(3), 571-610.

Sunder, S. (2009). IFRS and the Accounting Consensus. Accounting Horizons, 23(1), 101-111. https://doi.org/10.2308/acch.2009.23.1.101

Talesh, S. (2016). 7. Public law and regulatory theory. Handbook on Theories of Governance, 102.

Tsalavoutas, I., \& Dionysiou, D. (2014). Value relevance of IFRS mandatory disclosure requirements. Journal of Applied Accounting Research, 15(1), 22-42. https://doi.org/10.1108/JAAR-03-2013-0021

Uche, C. U. (2002). Professional accounting development in Nigeria: threats from the inside and outside. Accounting, Organizations and Society, 27(4), 471-496. https://doi.org/10.1016/S0361-3682(01)00007-1

van Zijl, T., \& Bradbury, M., E. (2006). Due process and the adoption of IFRS in New Zealand. Australian Accounting Review, 16(39), 86-94. https://doi.org/10.1111/j.1835-2561.2006.tb00363.x

Vashishtha, R. (2014). The role of bank monitoring in borrowers' discretionary disclosure: Evidence from covenant violations. Journal of Accounting and Economics, 57(2-3), 176-195. https://doi.org/10.1016/j.jacceco.2014.04.002

Wallace, R. S. O. (1987). Disclosure of accounting information in developing countries: A case study of Nigeria. Exeter University, London.

Watts, \& Zimmerman, J. (1978). Towards a Positive Theory of the Determination of Accounting Standards. The Accounting Review, 53(1), 112-134.

Watts, \& Zimmerman, J. (1986). Positive accounting theory. Englewood Cliffs, N.J. Prentice-Hall. 


\section{Macrothink \\ International Journal of Accounting and Financial Reporting ISSN 2162-3082 2018, Vol. 8, No. 1}

Zadek, S., Evans, R., \& Pruzan, P. (2013). Building corporate accountability: Emerging practice in social and ethical accounting and auditing. Routledge.

Zakari, M. A. (2014). Challenges of International Financial Reporting Standards (IFRS) Adoption in Libya. International Journal of Accounting and Financial Reporting. https://doi.org/10.5296/ijafr.v4i2.6302

Note

Note 1. Variables consist of a summated scale measured by the highest average of the items in the construct or the maximum mean of the construct.

\section{Copyright Disclaimer}

Copyright for this article is retained by the author(s), with first publication rights granted to the journal.

This is an open-access article distributed under the terms and conditions of the Creative Commons Attribution license (http://creativecommons.org/licenses/by/4.0/) 